\title{
EFEK PENAMBAHAN EPDM PADA KARET ALAM TERHADAP SIFAT MEKANIK KARET BUSA
}

\section{EPDM ADDITION EFFECTS ON NATURAL RUBBER MECHANICAL PROPERTIES OF RUBBER FOAM}

\author{
Nasruddin dan Aprillena Tornadez Bondan \\ Balai Riset dan Standardisasi Industri Palembang \\ Jl. Perindustrian II No. 12 Sukarami Km. 9 Palembang 30152 \\ email: nas.bppi@gmail.com
}

Diterima: 03 November 2018 ; Direvisi: 04 November - 20 November 2018; Disetujui: 27 November 2018

\begin{abstract}
Abstrak
Penelitian ini bertujuan untuk mempelajari sifat mekanik karet busa yang dihasilkan dari campuran karet sintetis ethylene propylene diene monomer rubber dengan karet alam SIR-20. Penelitian ini dibatasi pada tiga perlakuan dengan rasio campuran karet sintetis 0 phr; 2 phr; 4 phr, karet alam 100 phr; 98 phr; dan 96 phr. Natrium hidrokarbonat, fly ash dan bahan proses lainnya dikondisikan. Banyaknya busa yang terbentuk secara kualitatif digambarkan oleh nilai specific gravity terendah. Pengujian sifat mekanik seperti compression set, tear strength, tensile strength, dan elongation at break pada penelitian ini sebagai parameter pendukung. Hasil pengujian specific gravity terendah diperoleh dari perlakuan A yaitu $1,169 \mathrm{~g} / \mathrm{cm}^{3}$. Hasil pengujian parameter lainnya yaitu compression set $39,88 \%$, tear strength $20,8 \mathrm{kN} / \mathrm{m}$, tensile strength $14,8 \mathrm{MPa}$ dan elongation at break $680 \%$. Nilai specific gravity terendah pada perlakuan A secara kualitatif menggambarkan busa yang terbentuk lebih banyak dari perlakuan yang lainnya.
\end{abstract}

Kata Kunci: busa, campuran, karet alam, karet sintetis, sifat mekanik.

\section{Abstract}

This study aimed to study the mechanical properties of rubber foam produced from a mixture of ethylene propylene diene monomer (EPDM) rubber with SIR-20 natural rubber. This study was limited to three treatments with a ratio of synthetic rubber mixture 0 phr; 2 phr; 4 phr, and natural rubber 100 phr; 98 phr; and 96 phr. Sodium hydrocarbonate, fly ash and other process materials were conditioned. The amount of foam formed qualitatively was illustrated by the lowest specific gravity value. Testing of mechanical properties such as compression sets, tear strength, tensile strength, and elongation at break in this study were supporting parameters. The lowest specific gravity test results obtained from treatment $A$ was $1.169 \mathrm{~g} / \mathrm{cm}^{3}$. The other parameter test results were compression set $39.88 \%$, tear strength $20.8 \mathrm{kN} / \mathrm{m}$, tensile strength $14.8 \mathrm{MPa}$ and elongation at break $680 \%$. The lowest specific gravity value in treatment $A$ qualitatively described the foam formed more than the other treatments.

Keywords: foam, mixture, natural rubber, synthetic rubber, mechanical properties

\section{PENDAHULUAN}

Karet busa banyak digunakan untuk berbagai keperluan, terutama untuk rumah tangga, otomotif, industri, sebagai lapisan untuk menahan benturan benda yang mudah mengalami keretakan. Karet busa dengan sifat mekanik yang baik banyak digunakan sebagai insulator, pengemasan, material perisai elektromagnetik, komponen struktural dan peralatan medis (Shao et al., 2016; Mahamood et al., 2017).

Busa pada karet terbentuk akibat adanya udara terperangkap diantara molekul-molekul karet. Menurut Nalawade et al, (2006) karbon dioksida telah banyak digunakan untuk berbagai aplikasi pada pembuatan busa mikro seluler, modifikasi polimer, pembentukan komposit polimer, campuran polimer, dan proses polimerisasi.
Sifat mekanik karet busa dipengaruhi oleh sifat karet, densitas busa, ukuran dinding sel, jumlah sel, dan distribusi struktur sel (Basuli et al., 2012). Karet busa terdiri fase matriks polimer padat dan fase gas, dikenal sebagai karet spons dengan struktur sel terbuka, biasanya mengandung natrium bikarbonat sebagai agen pembentuk busa (Mohamad et al., 2015).

Bahan pembentuk busa pada umumnya digunakan sodium hidrokarbonat dengan bahan pengisi kalsium karbonat. Menurut Ariff at al, (2008) rasio natrium bikarbonat mempengaruhi ukuran sel, dinding sel, nilai kepadatan relatif dan tingkat pemampatan. Menutut Harahap, (2008) kalsium karbonat sebagai bahan pengisi dapat meningkatkan sambung silang yang berpengaruh terhadap densitas dan modulus bahan. Sementara bahan pengisi yang digunakan pada penelitian ini adalah fly ash. 
Menurut Sharma et al, (2015) fly ash mengandung lebih dari $70 \%$ silika cocok digunakan pada berbagai teknik aktivasi. Kalsium karbonat dan fly ash merukan mineral alam yang telah banyak digunakan sebagai bahan pengisi untuk meningkatkan sifat mekanik vulkanisat karet.

Karet busa telah lama dikembangkan terutama dari lateks yang berasal dari getah yang disadap dari pohon karet (Hevea brasiliensis Muell. Arg). Karet alam sebagai bahan untuk karet busa secara umum mempunyai keunggulan dimana sifat mekanik karet alam mempunyai elastisitas yang tinggi, pada saat dimampatkan atau menerima beban dapat kembali mendekati pada keadaan semula.

Untuk meningkatkan sifat mekanik karet alam menjadi barang jadi karet seperti karet busa perlu ditambahkan bahan activator, co-activator, bahan pengisi, anti oksidan bahan pemvulkanisasi dan bahan kimia lainnya. Penambahan bahan akan terjadi interaksi senyawa selain karet dengan rantai polyisoprene yang terbentuk untuk meningkatkan sifat mekanik karet alam, sementara asam amino, fenol, posfolifid dalam kompon selain karet mempengaruhi stabilitas karet (Jie et al., 2009).

Penelitian terkait pengembangan karet alam dari lateks pekat menjadi karet busa telah banyak dilakukan oleh peneliti sebelunya. Roslim et al., (2012) telah melakukan vulkanisasi lateks dari karet alam denga belerang dan peroksida menjadi busa lateks karet alam tipis yang memiliki struktur sel terbuka interkoneksi yang berkesinambungan. Salmazoa et al., (2016) telah melakukan penelitian karet busa dari karet alam dengan menghubungkan silang matriks polimer menggunakan sinar elektron energi tinggi pada dosis iradiasi yang berbeda (dari 50 hingga 150 kGy), busa yang diiradiasi pada dosis terendah struktur busa yang terbentuk lebih rentan terdegredasi, sementara busa disinari dengan dosis tertinggi menghasilkan struktur seluler yang lebih seragam. Tangboriboon et al, (2014) telah melakukan penelitian pengaruh natrium hidrokarbonat terhadap sifat mekanik karet busa yang menghasilkan kepadatan busa relative, crosslink densitas, pemampatan tetap, dan conductivitas thermal. Shey et al, (2006) telah melakukan penelitian sifat-sifat busa dari lateks dan pati, dimana pada penambahan aditif triton X-100 pada konsentrasi $\geq 0,05 \%$ mempunyai kemampuan untuk mencegah koagulasi.

Pengembangan karet alam menjadi karet busa pada penelitian ini dilakukan dengan menggunakan karet alam SIR-20 yang dikomposit dengan karet sintetis dari jenis ethylene propylene diene monomer rubber (EPDM). Lewis et al, (2003) telah melakukan penelitian pengembangan karet alam, EPDM, dan DNPT dengan campuran azodikarbonamida untuk menghasilkan busa. Vahidifar et al, (2016) telah mengembangkan karet alam dengan bahan pengisi carbon black untuk menghasilkan busa. Zakaria et al, (2007) telah mengembangan pengaruh temperatur pada pembuatan karet busa dari ethylene propylene diene monomer dengan sodium bicarbonate sebagai blowing agent.

Bahan pengembang untuk membentuk rongga-rongga udara yang membentuk busa digunakan sodium hidrokarbonat $\left(\mathrm{NaHCO}_{3}\right)$ dengan bahan pengis fly ash. Komposit EPDM dengan karet alam dapat meningkatkan ketahanan terhadap panas, pelapukan, memberikan kekuatan tarik yang stabil (Arayaprane and Rempel., 2007).

\section{BAHAN DAN METODA}

\section{Bahan}

Bahan yang digunakan terdiri dari karet alam-SIR-20, karet sintetis ethylene propylene diene monomer rubber (EPDM), titanium oksida $\left(\mathrm{TiO}_{2}\right)$, pigmen yellow, zink oksida $(\mathrm{ZnO})$, asam stearat, sodium hidrokarbonat $\left(\mathrm{NaHCO}_{3}\right)$, fly ash, polyethylene glycol-4000 (PEG-4000), dibenzothiazyldisulfie (MBTS), N-cyclohexyl-2benzothiazole sulfenamide (CBS) dan sulfur.

\section{Alat}

Alat yang digunakan terdiri dari open mill rubber, analytical balance capacity 3.200 gram merek Mettler Toledo ME3002, platen vulcanizing press, infrared thermometer merek KRISOWKW08-280, dan moulding.

\section{Rancangan Percobaan}

Penelitian ini dirancang dengan 3 (tiga) kali perlakuan seperti terlihat pada Tabel 1 . Karet busa yang dihasilkan dilakukan pengujian sifat mekanik dengan parameter yang meliputi specific gravity dengan metode uji ASTM D.207-15, compression set metode $25 \%$ at $700 \mathrm{C}, 72 \mathrm{hrs}$ D.395-16e1 meode uji ASTM D.395-16e1, tear strength metode uji ASTM D.624-00(ra2012), tensile strength metode uji ASTM D.412-16 dan elongation at break metode uji ASTM D.412-16. 
Tabel 1. Formula Karet Busa

\begin{tabular}{lrrr}
\hline \multicolumn{1}{c}{ Bahan } & \multicolumn{1}{c}{ A } & \multicolumn{1}{c}{ C } \\
\hline Karet Alam & 96 & 98 & 100 \\
EPDM & 4 & 2 & 0 \\
$\mathrm{TiO}_{2}$ & 2,85 & 2,85 & 2,85 \\
Pigmen Yellow & 1,75 & 1,75 & 1,75 \\
Zink Oksida & 4,25 & 4,25 & 4,25 \\
Asam Sreatrat & 2,25 & 2,25 & 2,25 \\
NaHCO $_{3}$ & 15,75 & 15,75 & 15,75 \\
Fly Ash & 5 & 5 & 5 \\
PEG-4000 & 1,25 & 1,25 & 1,25 \\
TMQ & 1,18 & 1,18 & 1,18 \\
MBTS & 1,65 & 1,65 & 1,65 \\
CBS & 0,55 & 0,55 & 0,55 \\
Sulfur & 2,25 & 2,25 & 2,25 \\
\hline
\end{tabular}

\section{Prosedur}

Karet sintetis dari jenis ethylene propylene diene monomer rubber dan karet alam masing-masing ditimbang sesuai formula (Tabel 1). Karet alam terlebih dahulu dimastikasi menggunakan penggiling terbuka (open mill) hingga plastis. Sambil terus digiling ditambahkan karet sintetis EPDM secara bersamaan hingga homogen. Selanjutnya sambil terus digiling ditambahkan titanium oksida hingga warna campuran karet alam dan karet sintetis menjadi putih. Sambil terus digiling lalu ditambahkan pigmen yellow hingga campuran (karet alam dan karet sintetis) seluruhnya menjadi kuning. Proses selanjutnya sambil terus digiling dengan open mill ditambahkan activator, co-activator sampai homogeny, selanjutnya ditambahkan bahan pengembang, dan bahan-bahan kimia lainnya seperti bahan pengisi bahan pencepat, anti oksidan. Setelah semua bahan homogen lalu ditambahkan sulfur sampai homogen. Kompon yang dihasilkan selanjutnya dicetak pada temperatur $125^{\circ} \mathrm{C} \pm$ $2^{\circ} \mathrm{C}$ selama 20 menit.

\section{Hasil}

\section{HASIL DAN PEMBAHASAN}

Hasil pengujian karet busa terdapat pada Tabel 2 berikut ini.

Tabel 2. Hasil Pengujian Karet Busa

\begin{tabular}{lrrr}
\hline \multirow{2}{*}{ Sifat Mekanik } & \multicolumn{3}{c}{ Formula } \\
\cline { 2 - 4 } & \multicolumn{1}{c}{ A } & \multicolumn{1}{c}{$\mathrm{B}$} & \multicolumn{1}{c}{$\mathrm{C}$} \\
\hline Specific Gravity $\left(\mathrm{g} / \mathrm{cm}^{3}\right)$ & 1,169 & 1,187 & 1,189 \\
Compression Set $(\%)$ & 39,88 & 31,92 & 36,42 \\
Tear Strength $(\mathrm{kN} / \mathrm{m})$ & 20,8 & 24,4 & 27,9 \\
Tensile Strength $(\mathrm{MPa})$ & 14,8 & 15,2 & 15,6 \\
Elongation at Break $(\%)$ & 680 & 650 & 620 \\
\hline
\end{tabular}

\section{Pembahasan}

\section{Specific Gravity}

Pengujian specific gravity ditujukan untuk melihat kerapatan bahan (kerapatan massa bahan) pembentuk karet busa dengan berat (gram) per satuan centimater cubik. Berat karet busa persatuan centimater cubik secara kualitatif dapat digunakan sebagai pertimbangan untuk memperkirakan adanya udara yang terperangkap pada saat bahan pengembang $\left(\mathrm{NaHCO}_{3}\right)$ dipanaskan membentuk rongga-rongga udara. Rongga udara yang terbentuk akibat dari $\mathrm{CO}_{2}$ terperangkap. Jumlah rongga udara yang terbentuk secara kualitatif pada penelitian ini dengan melihat perbedaan nilai specific gravity antar perlakuan. Dimana nilai specific gravity yang rendah dimungkinkan banyaknya gas $\mathrm{CO}_{2}$ yang terperangkap. Selain itu nilai specific gravity berhubungan dengan jumlah ikatan silang yang terjadi oleh interaksi antar bahan pembentuk (Syabani et al., 2017). Ikatan silang yang terbentuk berkaitan dengan sifat mekanik lainnya.

$\mathrm{NaHCO}_{3}$ sebagai bahan pengembang ketika dipanaskan pada saat pencetakan kompon menjadi karet busa terurai menuju ketekanan rendah, dimana gas $\mathrm{CO}_{2}$ terperangkap diantara molekul-molekul komposit vulkansast karet sintetis dan karet alam. Menurut Ariff et al, (2008) sodium bikarbonat dapat menghasilkan karbon dioksida yang membentuk busa karet. Gas $\mathrm{CO}_{2}$ yang terjebak (terperangkap) di dalam komposit karet sintetis dan karet alam akan membentuk rongga-rongga diantara molekul-molekul karet sintetis dan karet alam. Menurut Suriyachai et al, (2010) $\mathrm{NaHCO}_{3}$ sebagai agen pengembang pada saat dipanaskan terurai menjadi gas $\mathrm{CO}_{2}$ dengan ukuran sel yang terbentuk lebih kecil.

Banyaknya rongga udara yang terbentuk atau udara yang terperangkap di dalam komposit karet sintetis dan karet alam berpengaruh langsung terhadap nilai specific gravity. Jumlah rongga udara yang terbentuk oleh gas $\mathrm{CO}_{2}$ mengurangi kerapatan massa dan berat persatuan centimeter cubic karet busa yang dihasilkan. Ukuran sel yang terbentuk atau jumlah dan luas rongga yang terbentuk di dalam komposit karet alam dengan karet sintetis berpengaruh secara langsung terhadap nilai specific gravity. Menurut Ariff at al, (2007) busa dengan ukuran sel yang lebih kecil cenderung lebih tinggi massa jenisnya.

Data dari hasil penelitian pada Tabel 2 menunjukkan, nilai specific gravity terendah $\left(1,169 \mathrm{~g} / \mathrm{cm}^{3}\right)$ dari semua perlakuan (Tabel 1) terlihat pada perlakuan A. Hal ini menunjukkan, secara kualitatif jumlah ronga udara yang terbentuk persatuan centimeter cubic lebih banyak pada perlakuan $\mathrm{A}$ dibandingkan dengan perlakuan B dan perlakuan $\mathrm{C}$. Jika dilihat dari rasio karet sintetis dan karet alam menunjukkan 
bahwa untuk perlakuan $\mathrm{A}$ rasio karet sintetis dan karet alam $96: 4$.

Rasio karet sintesis dari jenis EPDM pada campuran karet alam dilihat dari hasil pengujian menunjukkan, semakin tinggi rasio karet sintetis maka jumlah rongga udara yang terbentuk semakin sedikit. Hal ini tergambar secara kualitatif dari hasil pengujian specific gravity. Sifat mekanik karet EPDM yang tidak elastis dapat menghambat terbentuknya rongga udara. Menurut Wang et al, (2006) spon dari EPDM memiliki sel yang sempit. Struktur dan sifat mekanik karet sintetis dari jenis EPDM lebih kokoh atau tidak elastis jika dibandingkan dengan karet alam. Etilena-propilena-diena terpolymer memiliki stabilitas kimia yang baik, dan memiliki resistensi yang baik (Wang et al., 2006). Dengan demikian semakin tinggi rasio karet sintetis yang ditambahkan, kemungkinan jumlah rongga udara yang terbentuk semakin kecil. Dimana karet alam sesuai dengan sifat mekaniknya merupakan elastomer yang sangat elastis, sementara elastisitas karet sintetis lebih rendah dari karet alam.

\section{Compression Set}

Pengujian compression set ditujukan untuk melihat kemampuan karet busa yang dihasilkan untuk menahan beban ketika ada tekanan yang membebaninya untuk kembali pada keadaan semula atau kembali mendekati pada keadaan semula. Karet alam sebagai polimer alami sesuai dengan sifat mekaniknya mempunyai elasstisitas yang baik dibanding karet sintetis.

Kemampuan karet busa menahan beban dan kembali pada keadaan semula dipengaruhi oleh rasio bahan (Tabel 1) yang membentuk struktur dinding sel dan rongga udara yang terbentuk. Selain itu specific gravity (Tabel 2) kekerasan, dan elastisitas berpengaruh terhadap nilai compression set. Dimana specific gravity menggambarkan kerapatan massa yang membentuk karet busa. Kerapatan massa pada saat ada benda yang membebaninya maka akan terjadi perlawanan sesuai dengan kekuatan ikatan antar molekul yang membentuknya. Kekuatan ikatan antar molekul yang membentuk karet busa seperti terlihat pada Tabel 1 dengan bahan utama komposit karet sintetis dan karet alam. Karet alam sesuai dengan sifat mekaniknya ketika ada benda yang membebaninya cenderung kembali pada keadaan semula lebih sempurna dibandingkan dengan karet sintetis yang mempunyai sifat yang kaku.

Karet sintetis dari jenis EPDM yang digunakan pada komposit karet alam tingkat elastisitasnya berbeda dengan karet alam. Rasio EPDM yang ditambahkan pada karet alam untuk membentuk karet busa sangat berpengaruh terhadap compression set ketika ada benda yang membebaninya. Selain itu komposit karet sintetis dengan karet alam pada saat ditambahkan natrium hidrokarbonat untuk membentuk ronggaronga udara diantara molekul komposit sangat dipengaruhi oleh jumlah karet sintetis yang ditambahkan. Menurut Zakaria et al, (2017) setruktur sel busa yang terbentuk pada karet EPDM dipengaruhi oleh sodium bicarbonate sebagai agen pembentuk busa dan temperatur.

Berdasarkan data hasil pengujian, compression set untuk masing-masing formula (Tabel 1) mempunyai perbedaan (Tabel 2), dimana untuk formula A lebih tinggi dibandingkan dengan formula ( $B$ dan $C$ ). Jika dilihat dari perbedaan nilai compression set yang diikuti oleh perbedaan nilai specific gravity, tear strength, tensile strength, dan elongation at break maka terlihat bahwa perbedaan rasio EPDM sangat berpengaruh terhadap sifat mekanik karet busa yang dihasilkan. Hal ini menunjukkan adanya korelasi yang mempengaruhi perbedaan nilai compression set dari setiap perbedaan rasio EPDM yang ditambahkan terhadap karet busa yang dihasilkan.

\section{Tear Strength}

Pengujian tear strength ditujukan untuk melihat ketahanan sobek karet busa terhadap gesekan atau sentuhan dengan benda lain. Kemampuan karet busa untuk menahan sobekan dari benda lain dipengaruhi oleh rasio bahan (Tabel 1) yang membentuknya. Rasio bahan menentukan ikatan sambung silang yang terjadi, dimana ikatan sambung silang yang terjadi memperkuat ikatan antar molekul dan dinding sel yang membentuk busa komposit karet alam dan EPDM. Reaksi sambung silang berlangsung pada saat pross vulkanisasi berlangsung dimana terjadi pencampuran antar bahan proses termasuk bahan pencepat yang ditambahkan (Norzalia et al., 1993; Hassan et al., 2003; dan Halimatuddahliana et al., 2005).

Jumlah dan struktur dinding sel yang terbentuk diantara rongga-rongga udara oleh gas $\mathrm{CO}_{2}$ dalam komposit karet alam dan EPDM sangat berpengaruh terhadap ketahanan sobek karet busa yang dihasilkan. Hasil pengujian tear strength pada Tabel 2 mengalami penurunan antara formula A $(39,88 \%)$ dengan formula C $(36,42)$, sementara untuk formula B $(31,92 \%)$ nilainya lebih kecil dibandingkan dengan formula A dan formula C. Jika dilihat dari rasio komposit antara EPDM dan karet alam menunjukan, rasio formula A karet alam 96, rasio karet EPDM 4, untuk formula B rasio karet alam 98, EPDM 2, dan untuk formula $C$ rasio karet alam 100, EPDM 0 . Hal ini menunjukkan, penurunan rasio EPDM yang diiringi dengan peningkatan karet alam berdampak terhadap perbedaan nilai tear strength. 


\section{Tensile Strength}

Pengujian tensile strength dilakukan untuk mengetahui sejauh mana karet busa yang dihasilkan dari rasio kompon (Tabel 1) untuk menahan tarikan (dengan arah yang berlawanan). Tensile strength pada karet busa berhubungan dengan elastisitas dan sifat mekanik bahan pembentuk yang digunakan. Nilai tensile strength karet busa pada penelitian ini menggambarkan tingkat elastisitas yang tinggi dari komposit karet alam dan EPDM. Karet EPDM sebagai komposit karet alam pada penelitian ini ditujukan untuk melengkapi kelemahan karet alam, dimana struktur molekul karet alam tidak tahan panas, cuaca ekstrim, dan minyak. Hal ini menyebabkan terjadi kelemahan sifat mekanik ketika karet alam dijadikan karet busa untuk ditempatkan pada udara terbuka. Kelemahan umumnya terjadi terutama pada saat cuaca ekstrim dimana akan terjadi penurunan sifat fisik seperti keretakan pada bagian permukaan yang berdampak pada rendahnya nllai tensile strength.

Dengan adanya komposit EPDM dengan karet alam dan bahan proses lainnya (Tabel 1) maka terjadi ikatan sambung silang yang membentuk struktur jaringan tiga dimensi yang menyebabkan dinding sel yang terbentuk dengan ikatan antar molekul menjadi kokoh. Menurut Hildayati et al, (2009) ikatan silang yang terjadi antar rantai karet dapat meningkatkan perpanjangan putus yang lebih besar.

Sifat mekanik karet alam dengan tingkat elastis yang baik dan plastis, menyebabkan vulkanisat komposit karet alam dengan EPDM menjadi karet busa memiliki sifat yang saling melengkapi. Menurut Helal and El-Sabbagh, (2005) campuran EPDM dan karet alam dapat meningkat nilai tensile strength. Selain itu proses vulkanisasi sangat menentukan homogenitas campuran bahan yang menyebabkan terjadinya ikatan sambung silang yang kokoh dan kuat.

Tensile strength sangat dipengaruhi oleh rasio campuran bahan yang optimum pada saat proses vulkanisasi, dan proses pencetakan yang terkendali. Penggunaan sulfur sebagai bahan sambung silang dalam komposit karet alam dan karet EPDM memperkuat struktur dinding sel yang dibentuk oleh karbon dioksida hasil dari penguraian natrium hidrokarbonat pada saat pencetakan.

Terbentuknya ikatan silang berdampak pada kenaikakan elastisitas (Indrajati dan Muhammad., 2014). Ikatan silang mempersatukan ikatan molekul karet alam yang dijembatani oleh atom sulfur dalam bentuk monosulfida, disulfida, maupun polisulfida (Santi et al., 2016). Dinding sel yang terbentuk pada saat terjadi tarikan karet busa dengan arah yang berlawanan memperlihatkan kemampuan molekul-molekul dari komposit yang terbentuk untuk berdeformasi yang memperkuar tensile strength.

Hasil pengujian tensile strength menunjukkak adanya peningkatan dari formula $A$ dengan rasio karet alam 96 EPDM 4 dengan nilai tensile strength $14,8 \mathrm{MPa}$. Selanjutnya terjadi peningkatan nilai tensile strength pada perlakuan B dimana rasio karet alam 98, rasio EPDM 2 dengan nilai tensile strength 15,2 $\mathrm{MPa}$, dan formula $C$ dengan rasio karet alam 100 , rasio EPDM 0 dengan nilai tensile strength 15,6 MPa.

Dilihat dari peningkatan nilai tensile strength diiringi dengan peningkatan rasio karet alam dan penurunan rasio karet EPDM ini menggambarkan tingkat elastisitas karet busa dari karet alam tanpa EPDM mempunyai kemampuan untuk menahan regangan yang disebabkan oleh tarikan berlawanan arah. Menurut Nabil et al, (2013) dan Nabil et al, (2014) perbedaan nilai tensile strength antar perlakuan dipengaruhi oleh kepadatan ikatan silang yang saling mengikat.

\section{Elongation at Break}

Pengujian elongation at break untuk menggambarkan pertambahan suatu benda pada saat dilakukan regangan sampai mengalami putus. Pada saat dilakukan regangan terjadi pergerakan molekul dan ikatan sambung silang untuk bertahan sampai pada keadaan dimana masing-masing molekul tidak dapat saling berikatan. Kemampuan bahan untuk menahan regangan dipengaruhi oleh kemampuan dan ikatan sambung silang yang membentuk benda dalam hal ini karet busa.

Bahan pengisi yang digunakan pada formula karet busa ini adalah fly ash dengan menggunakan PEG-4000. Kandungan silika yang terdapat dalam fly ash dengan bantuan PEG4000 dapat meningkatkan sifat mekanik struktur busa yang terbentuk. Menurut Dasgupta et al, (2013) fly ash sebagai bahan pengisi dapat membentuk algomerasi, meningkatkan crosslinks yang pada akhirnya meningkatkan kekuatan senyawa yang terbentuk.

Karet alam dikenal sebagai polimer non polar sementara bahan pengisi yang digunakan adalah bersifat polar, dengan demikian gaya adhesi dan interfase yang terjadi antara komposit karet alam dan EPDM dengan bahan pengisi dari fly ash masih lemah. Dengan demikian perlu penambahan jembatan penghubung dari jenis coupling agent. Penambahan PEG-4000 pada penelitian ini sebagai jembatan penghubung antara bahan pengisi dari fly ash dengan komposit karet alam dan karet EPDM. Coupling agent sebagai jembatan penghubung berfungsi untuk meningkatkan ikatan antar molekul dengan menurunkan energi permukaan karet alam dengan bahan pengisi (Nakason et al., 2006). Penurunan energy permukaan dengan tujuan 
untuk meningkatkan gaya adhesi sehingga terbentuk ikatan yang kuat dan kokoh.

Hasil pengujian elongation at break untuk tiga formula (Tabel 1) terlihat bahwa untuk formula $A$ nilai perpanjangan putusnya lebih tinggi $(680 \%)$ dibandingkan dengan formula B, dan formula $C$ (Tabel 2). Jika dilihat dari rasio komposit karet sintesis dan karet alam (Tabel 1) terlihat, pengaruh rasio komposit karet alam mempengaruhi nilai elongation at break. Dari data formula pada Tabel 1 , kenaikan rasio karet alam yang diiringi dengan penurunan rasio EPDM nilai elongation at break mengalami penurunan dari formula A $(680 \%)$ ke formula $B$ $(650 \%)$, selanjutnya menurun lagi ke formula $C$ menjadi $620 \%$.

Penambahan fly ash dengan rasio yang sama (5 phr) untuk semua perlakuan dimaksudkan untuk meningkatkan elongation at break, dimana fly ash mengandung unsur silika. Fly ash mengandung unsur silika 59,5\%, alumina $20,3 \%, \mathrm{FeO} / \mathrm{Fe}_{2} \mathrm{O}_{3} 6,5 \%$, sisanya berupa unsur $\mathrm{FeO}, \mathrm{MgO}$ dan berupa batubara yang tidak terbakar (Singla., and Vikas., 2010; Dasgupta et al., 2013). Silika merupakan bahan pengisi penguat yang dapat meningkatkan sifat mekanik vulkanisat. Menurut Hildayati et al (2019) silika dapat meningkatkan ikatan yang kuat antar permukaan dengan matriknya.

Silika yang terkandung dalam fly ash bersama dengan sulfur dalam matrix komposit EPDM dan karet alam bersama dengan PEG sebagai coupling agent dan bahan lainnya berpengaruh terhadap nilai kerapatan ikatan crosslink. Kerapatan ikatan crosslink yang terbentuk pada saat proses vulkanisasi dapat memperkuat struktur dinding sel yang membentuk karet busa. Ikatan crosslink yang membentuk dinding sel pada karet busa terjadi dari proses vulkanisasi yang merubah ikatan polisufida menjadi ikatan mono dan ikatan disulfida.

\section{KESIMPULAN}

Sifat mekanik karet busa berbahan komposit karet alam SIR-20 dengan karet sintetis jenis EPDM dari tiga formula telah dilakukan dan dipelajari. Hasil pengujian nilai specific gravity terendah diasumsikan sebagai gambaran jumlah busa yang terbentuk lebih banyak. Rongga udara terbentuk dari penguraian senyawa natrium hidrokarbonat menjadi gas karbon dioksida pada saat proses pencetakan. Pengujian specific gravity, compression set, tear strength, tensile strength dan elongation at break menggambarkan sifat mekanik karet busa yang terbentuk.

\section{UCAPAN TERIMA KASIH}

Ucapan terima kasih disampaikan pada Kepala Baristand Industri Palembang yang telah memberikan fasilitas penelitian, Direktur PT. Shima Prima Utama yang telah memberikan informasi terkait dengan penggunaan karet busa untuk alat-alat kesehatan, Para teknisi proses pengolahan karet PT. Shima Prima Utama yang telah membantu kegiatan pembuatn busa karet untuk sampel percobaan dan pengujian.

\section{DAFTAR PUSTAKA}

Ariff. Z.M., Rahim. N.A.A., and Low. L.C, (2008). Effect Of Compound Formulation On The Production And Properties of Epoxidised Natural Rubber (ENR-25) FOAMS. Proceedings of the Polymer Processing Society 24th Annual Meeting - PPS-24 June 15-19, 2008 Salerno (Italy)

Ariff. Z.M., Zakaria. Z., Tay. L.H., and Lee. S.Y. (2007). Effect of Foaming Temperature and Rubber Grades on Properties of Natural Rubber Foams. Journal of Applied Polymer Science, hal 2531-2538. DOI 10.1002/app.

Basuli. U., Lee. G.B., Jang. S.J., Oh. Lee, J.H., Kim. S.C., Jeon. N.D., Huh. J.I., and Nah. C. (2012). Foaming Behavior, Structure, and Properties of Rubber Nanocomposites Foams Reinforced with Zinc Methacrylate. Elastomers and Composites, 47(4): 297309.

doi: http://dx.doi.org/10.7473/EC.2012.47.4.297

Dasgupta. M., Saptarshi. K., Saikat. D.G., Rabindra. M., and Abhijit. B. (2013). Effect of Fly Ash as Filler in Rubber-A Comprehensive Study of the Vulcanisate Properties of Styrene Butadiene Rubber Compounds. Progress in Rubber, Plastics and Recycling Technology, 29(3): 151-168.

Halimatuddahliana., Ismail, H., and Akil, H.Md. (2005). The Effect of HVA-2 addition on the Properties of PP-EPDM-NR Ternary Blends, Journal Elastomers and Plastic, 37(1): 55-72. DOI: 10.1177/0095244305046487.

Harahap. H. (2008). Pengaruh Pengisi $\mathrm{CaCO}_{3}$ dan Temperatur Vulkanisasi Terhadap Sifat-Sifat Mekanikal Film Latex Karet. Jurnal Penelitian Rekayasa. 1(2): 43-46.

Helal. M.O.A., and El-Sabbagh. S.H. (2005). A Study on the Compatibility of NR-EPDM Blends Using Electrical and Mechanical Techniques. Journal of Elastomers and Plastics, Vol. 37; 319-346.

Hassan, A., Wahit, M.U. and Chee, C.Y. (2003). Mechanical and Morphological Properties of PP/NR/LLDPE Ternary Blend-Effect of HVA-2, Polymer Testing. 22(3): 281-290. 
Indrajati, I.N dan Muhammad, S. (2014). Pengaruh Rasio Mbts/Zdec Pada Campuran Karet Alam dan Etilen Propilen Diena Yang Dibuat dengan Teknik Kontrol Migrasi Curatives. Majalah Kulit, Karet, dan Plastik, 30(1): 43-52. DOI: 10.20543/mkkp.v30i1.124

Hildayati., Triwikantoro., Heny. F., dan Sudirman. (2009). Sintesis dan Karakterisasi Bahan Komposit Karet Alam-Silika. Seminar Nasional Pascasarjana IX - ITS, Surabaya 12 Agustus 2009. Hal. 1-8.

Jie. P.Z., Cheng. P.L., SI. D.L., Ling. X.K., Lei. Y., Shuang. Q.L., and Xiao. D.S. (2009). Study on the Properties of Natural Rubber During Maturation. J. Polym. Mater. 26(3): 351360.

Lewis. C., Rodlum. Y., Misaen. B., Changchum. S., and Sims. G.L.A. (2003). Effect of Compound Formulation and Processing Conditions on Properties of Extruded EPDM and NR/EPDM Foams. Cellular Polymers, Vol. 22(1): 43-56

Mahamood. M.A., Mohamad. N., Jeeffeerie. A.R., and Mohd. A.H.M. (2017). Correlation of Open Cell Structure with Properties of Green Rubber Foam from Epoxidised Natural Rubber/Reclaimed Rubber Glove. Journal of Mechanical Engineering, 1(1): 113-122.

Mohamad. N., Mazliah. M., Nur. Z.S., Amirul A..M.N., Abdollah. M.F.B., Hairul. E.A.M. (2015). Compressive Properties and Water Contact Behavior of Opened-Cell Green Rubber Foam at Different Blowing Agent Concentration. Proceedings of Malaysian International Tribology Conference 2015, pp. 86-87, November 2015.

Nabil. H., Ismail. H., and Azura, A.R. (2013). Comparison of Thermo-Oxidative Ageing and Thermal Analysis of Carbon BlackFilled NR/Virgin EPDM and NR/Recycled EPDM Blends. Polym. Test. 32: 631-639.

Nabil. H., Ismail. H., and Azura, A.R. (2014). Optimisation of Accelerators and Vulcanising Systems on Thermal Stability of natural rubber/recycled ethylenepropylene-diene-monomer blends. Mater. Des. 2014, 53, 651-661.

Nalawade. S.P., Francesco. P., and Janssen. L.P.B.M. (2006). Supercritical carbon dioxide as a green solvent for processing polymer melts: Processing aspects and applications. Prog. Polym. Sci. 31: 19-43.

Nakason, C.,Saiwari, S., and Kaesaman, A. (2006). Thermoplastic Vulcanizates Based on Maleated Natural Rubber/Polypropylene Blends: Effect of Blend Ratios on Rheological, Mechanical, and Morphological Properties. Polymer Engineering and Science, 46(5): 594-600. DOI 10.1002/pen.20498.
Norzalia, S., Surani, B. and Ahmad Fuad, M.Y. (1993). Studies on the Properties of PP/SMR and PP/ENR Blends, Journal of Industrial Technology. 3(2): 35-56.

Roslim. R., Amir. H.M.Y., and Augurio. P.T. (2012). Natural Latex Foam. Journal of Engineering Science, 8: 15-27.

Santi Puspitasari, Emil Budianto, dan Dadi Rusadi Maspanger. (2016). Pengaruh Rasio Karet Alam Terdeproteinisasi dengan Monomer Vinil terhadap Karakteristik Karet Alam Termoplastik. J. TIDP, 3(1): 1-10.

Salmazoa. L.O., Lopez-Gil. A., Ariff. Z.M., Jobc. A.E., Rodriguez. P.M.A. (2016). Influence of the Irradiation Dose in the Cellular Structure of Natural Rubber Foams CrossLinked by Electron Beam Irradiation. Industrial Crops and Products, 89: 339349.

Syabani MW., Perdana I., Rochmadi, (2017), Thermal Degradation of Modified PhenolFormaldehyde Resin with Sodium Silicate, Proceeding International Conference on Chemistry and Engineering in Agroindustry (ICoCheA 2017), Padang, pp. 37-40.

Sharma. A., Kabra. S., Katara. S., and Rani. A. (2015). Variation of Surface Morphology and Physico-Chemical Properties of the Fly Ash Through Mechanical and Thermal Activations Journal of Advanced Chemical Sciences 1(2): 70-74

Shey. J., Imam. S.H., Glenn. G.M., and Orts. W.J. (2006). Properties of baked starch foam with natural rubber latex. Industrial Crops and Products 24: 34-40

Shao. L., Zhan. Y.J., Jian. Z.M., Chao. H.X., Zhong. L.M., and Jing. Z. (2016). The Synergy of Double Cross-linking Agents on the Properties of Styrene Butadiene Rubber Foams. DOI: 10.1038/srep36931.

Singla. M., and Vikas. C. (2010). Mechanical Properties of Epoxy Resin - Fly Ash Composite. Journal of Minerals and Materials Characterization and Engineering, 9(3):199-210.

Suriyachai. P., Thavarungkul, N., and Sae-oui, P. (2010). Effects of Sodium Bicarbonate Content and Vulcanization Method on Properties of NBR/PVC Thermal Insulator Foam. International Journal of Materials and Metallurgical Engineering, 4(12): 737741.

Tangboriboon, N., and Anuvat. S. (2014). Effects of Foaming Agents and Calcium Carbonate on Thermo-Mechanical Properties of Natural rubber Foams. Polimeri. 35(12):10-17.

Vahidifar. A., Khorasani. S.N., Park. C.b., Naguib, H.N., and Khonakdar. H.A. (2016).Fabrication and Characterization of 
Closed-Cell Rubber Foams Based on Natural Rubber/Carbon Black by One-Step Foam Processing. Ind. Eng. Chem. Res. 2016, 55, 2407-2416. Ind. Eng. Chem. Res. 2016, 55, 2407-2416.

Wang, B.Q., Peng. Z.L., Zhang. Y., and Zhang. Y.X. (2006). Study on foaming kinetics and preparation of EPDM foams. Plastics,
Rubber and Composites, 35(9): 360-367. DOI 10.1179/174328906X149673

Zakaria. Z., Zulkifli. M.A., Tay. L.H., Coswald. S.S. (2017).Effect of Foaming Temperature on Morphology and Compressive Properties of Ethylene propylene diena monomer rubber (EPDM) Foam. Malaysian Polymer Journal (MPJ), 2(2): 22-30. 